\title{
UJI TOKSISITAS AKUT LOGAM TIMBAL (Pb), KROM (Cr) DAN KOBALT (Co) TERHADAP Daphnia magna
}

\author{
ACUTE TOXICITY TEST OF METAL LEAD (Pb), CHROMIUM (Cr) \\ AND COBALT (Co) ON Daphnia magna
}

\author{
Tivany Edwin, Taufiq Ihsan, Windy Pratiwi \\ Jurusan Teknik Lingkungan Universitas Andalas \\ Email: tivany@ft.unand.ac.id
}

\begin{abstract}
ABSTRAK
Penelitian ini bertujuan untuk menganalisis nilai $L C_{50}$ logam timbal (Pb), Krom (Cr), dan Kobalt (Co) yang terdapat pada limbah cair industri percetakan terhadap Daphnia magna serta menganalisis hubungan logam tersebut terhadap nilai $L_{50}$. Hasil pengukuran konsnetrasi logam $\mathrm{Pb}$ dan $\mathrm{Cr}$ tidak melebihi baku mutu yang ditetapkan, namun logam Co melebihi baku mutu. Toksisitas logam Pb, Cr, dan $\mathrm{Co}$ diuji dalam static test menggunakan larutan artifisial logam $\mathrm{Pb}, \mathrm{Cr}$, dan Co sesuai dengan konsentrasi terukur pada limbah cair. Pengujian dilakukan terdiri dari 2 tahap yaitu uji pendahuluan dan uji dasar. Data kematian Daphnia magna dianalisis menggunakan Metode Probit dengan program EPA Probit Analysis Program Version 1.5. Nilai $L_{50} 24$ jam logam Pb, Cr, dan Co terhadap Daphnia magna adalah $1,052 \%$ dan nilai $L C_{50} \operatorname{logam} \mathrm{Pb}, \mathrm{Cr}$, dan Co berturut-turut adalah 0,003 mg/l, 0,008 mg/l, dan 0,009 mg/l. Ketiga logam ini termasuk kategori sangat toksik terhadap Dahnia magna.
\end{abstract}

Kata Kunci: $P b, C r, C o$, Daphnia magna, $L C_{50}$,

\section{ABSTRACT}

This study aimed to analyze the LC50 value of metallic lead $(\mathrm{Pb})$, chromium $(\mathrm{Cr})$, and cobalt $(\mathrm{Co})$ contained in the printing industry wastewater to Daphnia magna and analyze the relationship of these metals to the LC50 value. The measurement results konsnetrasi $\mathrm{Pb}$ and $\mathrm{Cr}$ do not exceed the quality standards established, but the metals Co exceeds quality standards. Toxicity of $\mathrm{Pb}, \mathrm{Cr}$, and Co were tested in static test using artificial solution of $\mathrm{Pb}, \mathrm{Cr}$, and $\mathrm{Co}$ in accordance with the concentration measured in the wastewater. Tests carried out consisted of two stages: a preliminary test and test base. Daphnia magna mortality data were analyzed using Probit method with the EPA program Probit Analysis Program Version 1.5. 24-hour LC50 value of Pb, Cr, and Co to Daphnia magna is $1.052 \%$ and the LC50 values of $\mathrm{Pb}, \mathrm{Cr}$, and Co are respectively $0.003 \mathrm{mg} / \mathrm{l}, 0.008 \mathrm{mg} / \mathrm{l}$ and 0.009 $\mathrm{mg} / \mathrm{l}$. All three metals have included the category of very toxic to Dahnia magna.

Keywords: Pb, Cr, Co, Daphnia magna, LC50 


\section{PENDAHULUAN}

Menurut Setiyono (2002), limbah percetakan koran mengandung beberapa logam berat diantaranya timbal $(\mathrm{Pb})$, krom $(\mathrm{Cr})$, dan kobalt (Co). Peraturan mengenai limbah percetakan diatur dalam Peraturan Menteri Lingkungan Hidup No. 5 Tahun 2014 tentang Baku Mutu Air Limbah. Peraturan ini mengatur beberapa parameter limbah diantaranya adalah baku mutu logam-logam yang ada di dalam limbah percetakan, yaitu timbal $(\mathrm{Pb})$, krom $(\mathrm{Cr})$, kobalt $(\mathrm{Co})$.

Meskipun tidak menghasilkan limbah dalam jumlah besar, namun karena sifat limbahnya yang berbahaya dan beracun maka dampak yang ditimbulkan harus diwaspadai. Logam berat sifatnya sangat unik, tidak dapat dihancurkan secara alami dan cenderung terakumulasi dalam rantai makanan (Darmono, 1995). Pencemaran logam berat menimbulkan dampak negatif bagi ekosistem perairan karena sifatnya yang persisten dan mudah terakumulasi dalam jaringan tubuh biota (Oktaviyanti, 2012).

Uji toksisitas akut merupakan salah satu bentuk penelitian toksikologi perairan. Uji tersebut berfungsi untuk mengetahui atau mengidentifikasi apakah effluent dan badan air penerima mengandung senyawa toksik dalam konsentrasi yang menyebabkan toksisitas pada organisme akuatik. Parameter yang diukur biasanya berupa immobilisasi atau kematian hewan uji. Hasilnya dinyatakan sebagai konsentrasi yang menyebabkan $50 \%$ kematian hewan uji $\left(\mathrm{LC}_{50}\right)$ dalam waktu yang relatif pendek satu sampai empat hari.

Biota uji yang sering digunakan dalam uji toksisitas yang telah diakui sebagai bioindikator toksisitas perairan oleh organisasi internasional seperti United States Environmental Protection Agency (USEPA) adalah ikan, Crustaceae, dan alga. Dalam penelitian ini digunakan Daphnia magna sebagai wakil dari Crustaceae dalam pengujian toksisitas akut. Penggunaan Daphnia magna pada penelitian ini karena Daphnia magna merupakan hewan uji yang paling sensitif terhadap bahan kimia seperti logam berat, berperan dalam ekologi sebagai sumber makanan, laju pertumbuhan yang cepat, tingkat reproduksi yang tinggi, dan siklus hidup yang pendek. Jika keberadaan
Daphnia magna terancam oleh pencemaran logam berat maka akan mengurangi sumber makanan di perairan dan beresiko terhadap akumulasi dari kontaminasi logam berat untuk rantai makanan selanjutnya.

Penelitian oleh Sari (2012) mengenai Toksisitas Logam Kromium (Cr) terhadap Daphnia magna menghasilkan nilai $\mathrm{LC}_{50} 24$ jam yaitu 26,81 mg/l dan $\mathrm{LC}_{50} 48$ jam 13,13 $\mathrm{mg} / \mathrm{l}$. Toksisitas akut logam $\mathrm{Pb}$ diteliti oleh Teodorovic, dkk (2008) menghasilkan nilai $\mathrm{LC}_{50} 24$ jam yaitu 208,14 mg/l dan $\mathrm{LC}_{50} 48$ jam yaitu $74,73 \mathrm{mg} / \mathrm{l}$. Penelitian mengenai toksisitas logam Co terhadap Daphnia magna dilakukan oleh Little, dkk (2007) menghasilkan nilai $\mathrm{LC}_{50} 48$ jam adalah 1,5 $\mathrm{mg} / \mathrm{l}$. Pengujian toksisitas akut logam $\mathrm{Pb}$ dan Cr juga dilakukan terhadap Daphnia magna yang menghasilkan $\mathrm{LC}_{50} \mathrm{~Pb} 23,136 \mathrm{mg} / \mathrm{l}$ dan $\mathrm{Cr} 12,225 \mathrm{mg} / \mathrm{l}$ (Oktaviyanti, 2012). Pengujian toksisitas akut terhadap logam $\mathrm{Pb}$, Cr, dan Co terhadap Daphnia magna sudah banyak dilakukan namum pengujian toksisitas akut terhadap logam $\mathrm{Pb}, \mathrm{Cr}$, dan Co terhadap Daphnia magna belum ada dilakukan.

Sehubungan dengan hal di atas maka pada penelitian ini dilakukan pengujian toksisitas akut logam $\mathrm{Pb}, \mathrm{Cr}$, dan $\mathrm{Co}$ dalam limbah cair industri percetakan PT. X di Kota Padang terhadap Daphnia magna. Tujuan penelitian ini adalah untuk menganalisis nilai $\mathrm{LC}_{50}$ logam berat $\mathrm{Pb}, \mathrm{Cr}$ dan Co yang terdapat pada limbah cair terhadap Daphnia magna.

\section{METODOLOGI}

Uji toksisitas dilakukan dengan cara teknik statis dimana selama uji berlangsung tidak dilakukan penggantian larutan maupun pemindahan organisme uji. Penelitian terdiri dari dua tahap yaitu uji pendahuluan atau range finding test dan uji dasar atau defenitif test. Biota uji yang sering digunakan dalam uji toksisitas yang telah diakui sebagai bioindikator toksisitas perairan oleh organisasi internasional seperti United States - Environmental Protection Agency (US-EPA) adalah ikan, crustaceae, dan alga. Dalam penelitian ini digunakan Daphnia magna sebagai wakil dari Crustaceae dalam pengujian toksisitas akut. 
Adapun alat dan bahan yang diperlukan pada penelitian ini adalah Akuarium ukuran 30 $\mathrm{cm} \times 25 \mathrm{~cm}$ x $20 \mathrm{~cm}$ sebanyak 3 buah dan aerator yang digunakan untuk kultur Daphnia magna; Botol berukuran $100 \mathrm{ml}$ sebanyak 30 buah digunakan untuk wadah uji; Gelas ukur $50 \mathrm{ml}$ digunakan untuk mengukur larutan uji; Pipet tetes digunakan untuk memindahkan Daphnia magna; $\mathrm{pH}$ meter, DO meter, dan termometer digunakan untuk mengukur parameter fisik dan kimiawi (pH, DO, dan suhu).

Sedangkan bahan yang dipergunakan adalah

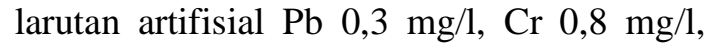
dan Co $0,9 \mathrm{mg} / \mathrm{l}$ sesuai dengan konsentrasi logam pada limbah cair industri percetakan; Daphnia magna berumur kurang dari 24 jam. Selama pengembangbiakan Daphnia magna dibutuhkan pelet (makanan) ikan sebagai sumber makanannya; dan kuades untuk kultur dan pengujian.

Daphnia magna diperoleh dari Puslitbang Sumber Daya Air Bandung dan dikultur kembali di Ruang Penelitian Jurusan Teknik Lingkungan Fakultas Teknik Universitas Andalas Padang sampai jumlahnya mencukupi untuk uji toksisitas. Selama masa kultur, media tetap diaerasi dan Daphnia magna diberi pakan ikan yang sudah dilarutkan setiap hari.

Sebelum Daphnia magna dikultur, akuades sebagai medium diaerasi terlebih dahulu selama kurang lebih 24 jam. Daphnia magna dan air dari sumbernya dimasukan kedalam akuarium kemudin ditambah dengan air medium yang sudah diaerasi sebelumnya. Tujuan ditambah akuades yang diaerasi untuk memberikan oksigen yang baru terhadap Daphnia magna. Daphnia magna yang kultur lebih kurang 1000 ekor selama lebih kurang 3 hari.

Setelah pengulturan kemudian dipilih Daphnia magna dewasa yang siap bereproduksi. Pemilihan species ini berdasarkan morfologi dari Daphnia magna yang memiliki telur dibagian posterior dari tubuhnya. Subkultur dilakukan dengan cara pemindahan induk Daphnia magna yang akan bereproduksi kedalam akuarium yang baru dan media kultur yang sama di akuarium yang berbeda. 2 akuarium digunakan untuk masing-masing subkultur untuk masing-masing pengujian. Setelah subkultur dilakukan maka akan didapatkan neonate yang berumur kurang dari 24 jam. Subkultur ini dilakukan untuk mendapatkan Daphnia magna yang digunakan dalam uji toksisitas.

Pembuatan larutan artifisial dimulai dengan membuat larutan induk logam $\mathrm{Pb}, \mathrm{Cr}$, dan Co masing-masing $1000 \mathrm{ppm}$. Untuk mempermudah pengenceran untuk pembuatan laruta artifisial maka dilakukan pengenceran larutan induk dari 1000 ppm ke 100 ppm terlebih dahulu. Larutan masingmasing logam 100 ppm kemudian diencerkan sesuai dengan konsentrasi yang dibutuhkan yaitu $\mathrm{Pb} 0,3 \mathrm{mg} / \mathrm{l}, \mathrm{Cr} 0,8 \mathrm{mg} .1$, dan Co 0,9 mg/l.

Tahapan penelitian ini terdiri dari tahapan aklimatisasi Daphnia magna, tahapan dan acuan melakukan uji pendahuluan dan uji dasar.

\section{Aklimatisasi Hewan Uji}

Aklimatisasi Daphnia magna dilakukan pada medium akuades selama kurang lebih 2 jam sebelum pelaksanaan uji toksisitas. Aklimatisasi dilakukan masing-masing untuk uji pendahuluan dan uji dasar. Uji pendahuluan dilakukan untuk mengetahui konsentrasi limbah tertinggi yang menyebabkan kematian total Daphnia magna selama 24 jam sesuai dengan yang dianjurkan USEPA (2002).

\section{Uji Pendahuluan}

Uji toksisitas ini dilakukan dengan menggunakan botol vial berukuran $100 \mathrm{ml}$. Setiap botol vial berisi larutan artifisial $\mathrm{Pb}$, $\mathrm{Cr}$, dan Co dengan konsentrasi $100 \%, 50 \%$, $25 \% 12,5 \%, 6,25 \%$ dan $0 \%$ sebagai kontrol. Konsentrasi ini dipilih karena berdasarkan USEPA (2002) nilai faktor pengenceran $\geq$ 0,5 digunakan untuk menentukan konsentrasi limbah yang akan diuji. Setiap botol vial diisi $50 \mathrm{ml}$ larutan artifisial dan 10 ekor Daphnia magna. Pengamatan/pengulangan terhadap uji pendahuluan dilakukan sebanyak 5 kali sehingga uji pendahuluan dan uji dasar membutuhkan 30 pengamatan untuk masingmasing uji.

Jumlah Daphnia magna yang mati dan yang masih hidup dicatat dan uji ini dilakukan selama 24 jam. Pemilihan durasi 24 jam 
karena berdasarkan penelitian oleh Oktaviyanti (2012) yang melakukan optimasi kontrol untuk mendapatkan durasi uji toksisitas akut terhadap Daphnia magna. Penelitian tersebut menghasilkan Daphnia magna dapat hidup optimal selama 24 jam. Pengukuran parameter fisik dan kimiawi (pH, DO, dan suhu) dilakukan sebagai penunjang uji toksisitas. Pengukuran dilakukan diawal dan diakhir perlakuan dan nantinya akan diambil rata-ratanya. Hasil uji dapat dikatakan benar jika pada akhir pengamatan pada kontrol masih terdapat 90\% hewan uji yang masih hidup (USEPA, 2002).

\section{Uji Dasar}

Uji selanjutnya adalah uji dasar sebagai lanjutan dengan prosedur yang hampir sama dengan uji pendahuluan. Pada uji dasar ini digunakan konsentrasi pengenceran yang dipersempit atau berada dalam rentang konsentrasi terendah dan tertinggi. Uji dasar ini bertujuan untuk mendapatkan nilai $\mathrm{LC}_{50}$ akhir. Data kematian Daphnia magna diamati setelah pengujian.

Tahapan setelah penelitian merupakan tahap analisis data. Nilai $\mathrm{LC}_{50}$ didapat dengan menganalisis data kematian hewan uji. Analisis data dilakukan setelah pengumpulan data hasil uji pendahuluan dan uji dasar. Metode yang digunakan untuk mengestimasi nilai $\mathrm{LC}_{50}$ adalah grafik, metode Spearman-Karber, metode Trimmed Spearman-Karber dan metode Probit yang dipilih berdasarkan jumlah kematian hewan uji. Hasil analisis data diperoleh nilai $\mathrm{LC}_{50} 24$ jam yang mengindikasikan nilai konsentrasi logam $\mathrm{Pb}$, $\mathrm{Cr}$, dan Co pada limbah industri percetakan koran yang mengakibatkan $50 \%$ kematian hewan uji selama 24 jam.

\section{HASIL DAN PEMBAHASAN}

\section{Uji Pendahuluan}

\section{Aklimatisasi Hewan Uji}

Populasi hewan uji ini dianggap memenuhi syarat untuk pengujian jika dalam waktu 2 jam hewan uji yang boleh mati $\leq 3 \%$ dari populasi hewan uji yang diaklimatisasi. Daphnia magna bertahan hidup $100 \%$ atau tidak ada kematian setelah diaklimatisasi selama 2 jam. Sehingga Daphnia magna yang diaklimatisasi layak dijadikan hewan uji.

\section{Parameter pH, DO, dan suhu}

Parameter $\mathrm{pH}$, DO, dan suhu merupakan parameter yang mempengaruhi kehidupan Daphnia magna. Parameter tersebut sebaiknya menunjang kehidupan Daphnia magna selama uji agar tidak mempengaruhi hasil pengujian. Gambar $\mathbf{1 , 2}$ dan 3 menunjukkan hasil rata-rata pengukuran parameter fisik ( $\mathrm{pH}$, suhu, dan Do) pada pengamatan yang dilakukan selama 24 jam.

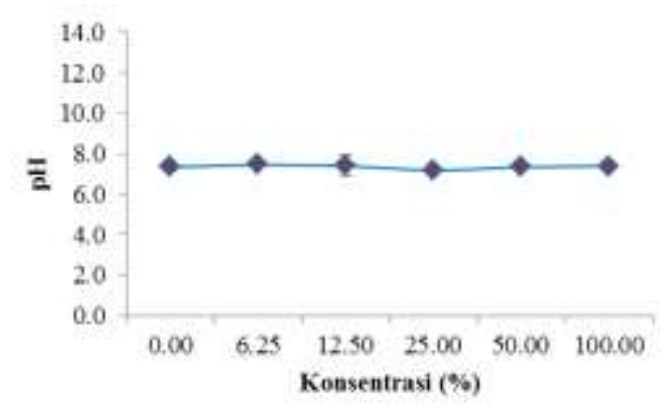

\section{Gambar 1. Pengukuran pH pada Uji} Pendahuluan

Berdasarkan Gambar 1 dapat ditarik kesimpulan bahwa pada pengujian dilakukan $\mathrm{pH}$ larutan uji berkisar antara 7,1 - 8,3. Rentang $\mathrm{pH}$ ini berada pada rentang $\mathrm{pH}$ yang dianjurkan dalam siklus hidup optimal Daphnia magna yaitu 7-2 - 8,5 (Clare, 2002).

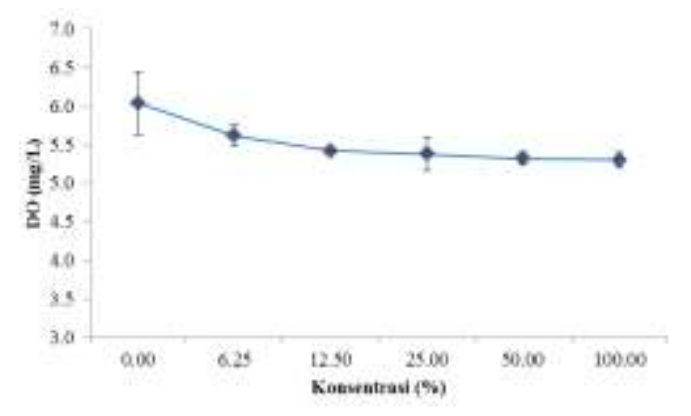

\section{Gambar 2. Pengukuran DO pada Uji Pendahuluan}

Berdasarkan Gambar 2 dapat ditarik kesimpulan bahwa pada pengujian dilakukan DO larutan uji berkisar antara 5,0 - 6,6 mg/l. Rentang DO ini berada di atas DO yang dianjurkan dalam siklus hidup optimal Daphnia magna yaitu $>3 \mathrm{mg} / \mathrm{l}$ (Ebert, 2005). Kondisi ini sangat baik untuk Daphnia magna karena DO atau oksigen terlarut 
tersebut sangat dibutuhkan oleh Daphnia magna dalam proses metabolisme di dalam tubuhnya. Kandungan DO merupakan indicator penting kualitas perairan, karena DO berperan dalam proses oksidasi dan reduksi bahan organic dan anorganik dalam air. Apabila kadar DO di air tidak tersedia dalam jumlah yang cukup akan menyebabkan kualitas air menurun dan dapat mengakbatkan kematian pada perairan.

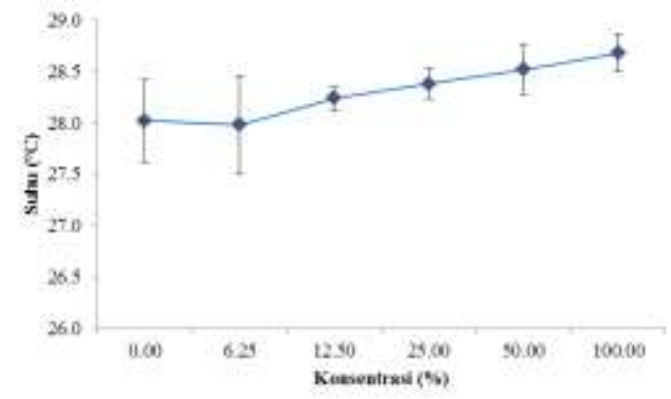

\section{Gambar 3. Pengukuran Suhu pada Uji Pendahuluan}

Berdasarkan Gambar 3 dapat ditarik kesimpulan bahwa pada pengujian dilakukan suhu larutan uji berkisar antara $27,6^{\circ} \mathrm{C}-$ $28,8^{\circ} \mathrm{C}$. Rentang suhu ini berada pada rentang suhu optimal dalam siklus hidup Daphnia magna yaitu $22^{\circ} \mathrm{C}-31^{\circ} \mathrm{C}$ (Radini, 2004).

Data pengamatan ini menunjukkan bahwa $\mathrm{pH}$, DO dan suhu air selama pengujian masih masuk dalam rentang yang dianjurkan untuk kehidupan Daphnia magna. Kondisi $\mathrm{pH}$, suhu, dan DO dijaga agar Daphnia magna dapat hidup secara optimal. Sehingga dapat ditarik kesimpulan bahwa kematian Daphnia magna disebabkan oleh pencemar yang ada dalam larutan uji.

\section{Nilai LC S0 $_{50}$ Uji Pendahuluan}

Uji pendahuluan dilakukan untuk menentukan batas kisaran kritis (critical range test) yang menjadi dasar dari penentuan konsentrasi yang digunakan dalam uji dasar atau uji toksisitas sesungguhnya, yaitu konsentrasi yang dapat menyebabkan kematian terbesar mendekati $50 \%$ dan kematian terkecil mendekati 50\%.

Uji toksisitas ini menggunakan larutan artifisial dengan multikonsentrasi yaitu $\mathrm{Pb}$ sebesar 0,3 mg/l, Cr sebesar 0,8 mg/l, dan Co sebesar 0,9 mg/l. Persentase larutan pada uji pendahuluan ini sesuai dengan USEPA yaitu $6,25 \%, 12,5 \%, 25 \%, 50 \%, 100 \%$ dan kontrol $(0 \%)$ dengan faktor pengenceran 0,5 . Percobaan ini dilakukan masing-masing dengan 5 kali pengulangan. Jumlah kematian rata-rata Daphnia magna pada uji pendahuluan dapat dilihat pada Gambar 4.

Berdasarkan data jumlah kematian Daphnia magna pada Gambar 4 terdapat rata-rata 1 kematian pada konsentrasi $0 \%$ yang merupakan kontrol. Hal ini menyatakan hasil pengujian yang dilakukan benar dan dapat diterima karena syarat keberhasilan pengujian adalah jika diakhir pengamatan konsentrasi kontrol masih terdapat $\geq 90 \%$ hewan uji (USEPA, 2002).

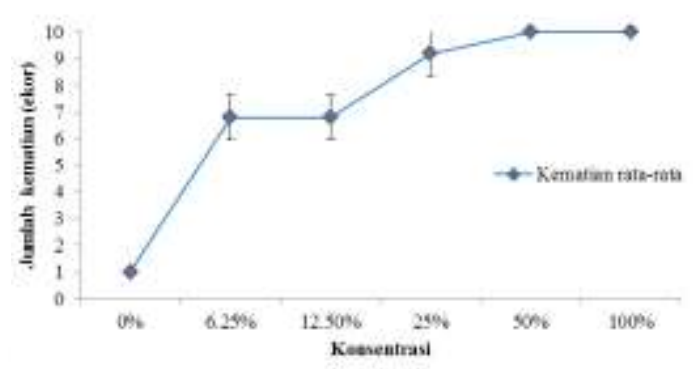

Gambar 4. Jumlah Kematian Rata-rata Daphnia magna pada Uji Pendahuluan

Gambar 4. menunjukkan bahwa semakin tinggi konsentrasi pencemar semakin banyak jumlah kematian pada hewan uji dan sebaliknya semakin kecil konsentrasi pencemar semakin kecil jumlah kematian pada hewan uji. Hal ini membuktikan senyawa-senyawa toksik pada larutan uji berpengaruh terhadap kematian hewan uji. Data kematian Daphnia magna digunakan sebagai data untuk menentukan metode analisis yang akan dipakai. Terdapat dua atau lebih konsentrasi yang menyebabkan kematian hewan uji, sehingga nilai $\mathrm{LC}_{50}$ ditentukan menggunakan metode probit. Setelah diolah pada program probit didapatkan nilai $\mathrm{LC}_{50}$ logam $\mathrm{Pb}, \mathrm{Cr}$, dan $\mathrm{Co}$ terhadap Daphnia magna adalah 5,060\% dengan batas tertinggi pada konsentrasi $10,150 \%$ dan terendah pada konsentrasi $0,046 \%$. Batas konsentrasi ini digunakan sebagai referensi konsentrasi untuk melakukan uji dasar. 


\section{Uji Dasar}

\section{Aklimatisasi Hewan Uji}

Sebelum melakukan uji dasar dilakukan kembali aklimatisasi hewan uji seperti sebelumnya pada uji pendahuluan. Daphnia magna yang berumur <24 jam dimasukan kedalam akuades selama 2 jam. Daphnia magna mengalami kematian 5 ekor dari total populasi aklimatisasi 320 ekor. Pada aklimatisasi ini Daphnia magna mati $\leq 3 \%$ dari populasi total. Sehingga Daphnia magna yang diaklimatiasi layak dijadikan hewan uji.

\section{Parameter pH, DO, dan Suhu}

Parameter $\mathrm{pH}$, DO, dan suhu merupakan parameter yang mempengaruhi kehidupan Daphnia magna. Parameter tersebut sebaiknya menunjang kehidupan Daphnia magna selama uji agar tidak mempengaruhi hasil pengujian nantinya. Gambar 5, 6 dan 7 menunjukkan hasil rata-rata pengukuran parameter fisik $(\mathrm{pH}$, suhu, dan Do) pada pengamatan yang dilakukan selama 24 jam.

Berdasarkan Gambar 5 dapat ditarik kesimpulan bahwa pada pengujian dilakukan $\mathrm{pH}$ larutan uji berkisar antara 7,4 - 8,1. Rentang $\mathrm{pH}$ ini berada pada rentang $\mathrm{pH}$ yang dianjurkan dalam siklus hidup optimal Daphnia magna yaitu 7-2 - 8,5 (Clare, 2002).

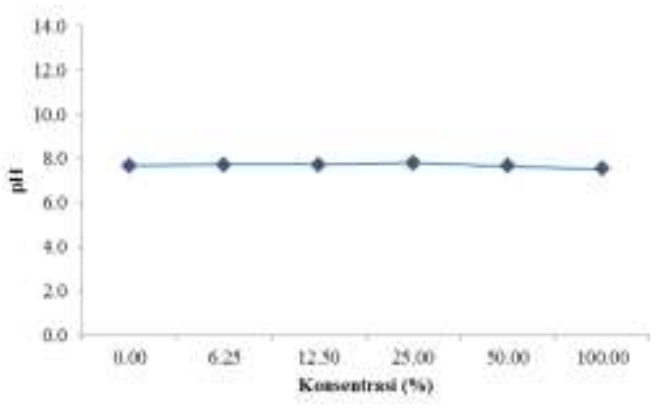

Gambar 5. Pengukuran pH pada Uji Dasar

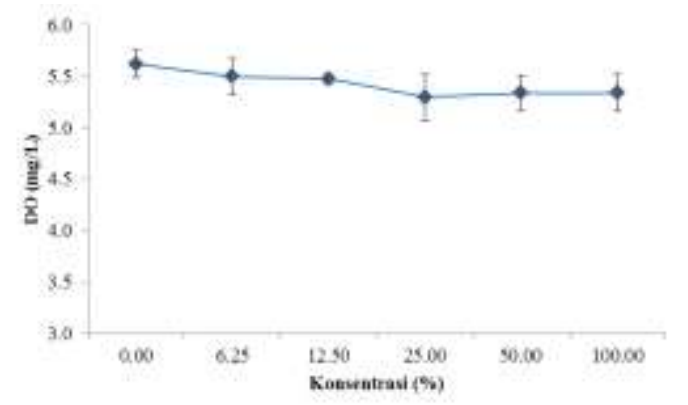

Gambar 6. Pengukuran DO pada Uji Dasar
Berdasarkan Gambar 6 dapat ditarik kesimpulan bahwa pada pengujian dilakukan DO larutan uji berkisar antara 5,0 - 6,6 mg/l. Rentang DO ini berada di atas DO yang dianjurkan dalam siklus hidup optimal Daphnia magna yaitu $>3 \mathrm{mg} / \mathrm{l}$ (Ebert, 2005). Kondisi ini sangat baik untuk Daphnia magna karena DO atau oksigen terlarut tersebut sangat dibutuhkan oleh Daphnia magna dalam proses metabolisme di dalam tubuhnya. Kandungan DO merupakan indicator penting kualitas perairan, karena DO berperan dalam proses oksidasi dan reduksi bahan organik dan anorganik dalam air. Apabila kadar DO di air tidak tersedia dalam jumlah yang cukup akan menyebabkan kualitas air menurun dan dapat mengakbatkan kematian pada perairan.

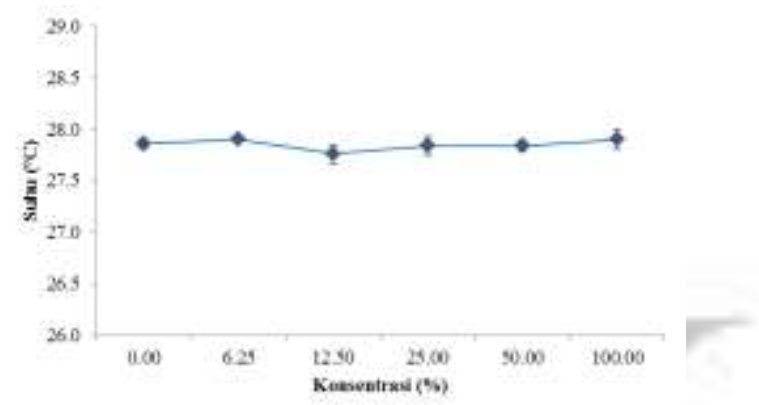

Gambar 7 Pengukuran Suhu pada Uji Dasar

Berdasarkan Gambar 7 dapat ditarik kesimpulan bahwa pada pengujian dilakukan suhu larutan uji berkisar antara $27,6^{\circ} \mathrm{C}-$ $28,8^{\circ} \mathrm{C}$. Rentang suhu ini berada pada rentang suhu optimal dalam siklus hidup Daphnia magna yaitu $22^{\circ} \mathrm{C}-31^{\circ} \mathrm{C}$ (Radini, 2004).

Data pengamatan ini menunjukkan bahwa $\mathrm{pH}$, DO dan suhu air selama pengujian masih masuk dalam rentang yang dianjurkan untuk kehidupan Daphnia magna. Kondisi $\mathrm{pH}$, suhu, dan DO dijaga agar Daphnia magna dapat hidup secara optimal. Sehingga dapat ditarik kesimpulan bahwa kematian Daphnia magna disebabkan oleh pencemar yang ada dalam larutan uji.

\section{Nilai LC $_{50}$ pada Uji Dasar}

Uji dasar atau uji toksisitas dilakukan setelah uji pendahuluan dengan menggunakan larutan artifisial multikonsentrasi yaitu $\mathrm{Pb}$ sebesar 0,3 mg/l, Cr sebesar 0,8 mg/l dan Co sebesar $0,9 \mathrm{mg} / \mathrm{l}$. Batas konsentrasi yang 
digunakan merujuk kepada hasil uji pendahuluan. Adapun batas konsentrasi yang digunakan berkisar antara 0,046\% $10,150 \%$. Berdasarkan seri logaritmik, maka persentase larutan uji yang digunakan adalah $1,5 \% ; 2,5 \% ; 3,2 \% ; 4,6 \% ; 6,8 \%$ karena rentang konsentrasi berada pada $0 \%-10 \%$. Data jumlah kematian Daphnia magna pada uji dasar dapat dilihat pada Gambar 8.

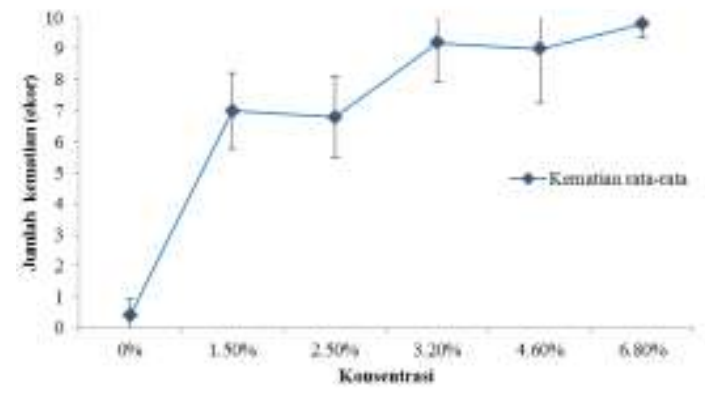

\section{Gambar 8. Jumlah Kematian Rata-rata Daphnia magna pada Uji Dasar}

Hasil dari program probit didapatkan nilai $\mathrm{LC}_{50}$ logam $\mathrm{Pb}, \mathrm{Cr}$, dan Co terhadap Daphnia magna adalah $1,052 \%$ dengan batas tertinggi pada konsentrasi $0,000 \%$ dan terendah pada konsentrasi $1,798 \%$. Nilai $\mathrm{LC}_{50}$ ini merupakan nilai akhir dari pengujian tokisitas.

Nilai LC $_{50}$ ini dikonversi ke masing-masing konsentrasi toksikan. Didapatkan nilai $\mathrm{LC}_{50}$ masing-masing logam yakni $\mathrm{LC}_{50} \operatorname{logam} \mathrm{Pb}$ $0,003 \mathrm{mg} / \mathrm{l}, \mathrm{LC}_{50}$ logam $\mathrm{Cr} 0,008 \mathrm{mg} / \mathrm{l}$ dan $\mathrm{LC}_{50} \operatorname{logam}$ Co $0,009 \mathrm{mg} / \mathrm{l}$.

\section{SIMPULAN}

Semakin tinggi konsentrasi logam $\mathrm{Pb}, \mathrm{Cr}$, dan Co yang terdapat dalam limbah, maka kematian Daphnia magna semakin besar, sehingga nilai LC juga akan semakin besar, begitu juga sebaliknya. Kecenderungan logam $\mathrm{Pb}, \mathrm{Cr}$, dan $\mathrm{Co}$ terhadap nilai LC dengan nilai $r=0,983$ menunjukan bahwa konsentrasi logam sangat kuat mempengaruhi nilai LC.

\section{DAFTAR PUSTAKA}

APHA. (1995). Standar Methods for The Examination of Water and Waste water, American Public Health Assosiation, American Water Works Assosiation and Water Polution Control Federation. Edisi ke-14. Washington DC.
Atlindag, A., Ergonul, M. B., Yigit, dan S., Baykan, O. (2008). The Acute Toxicity of Lead Nitrate on Daphnia magna Straus. African Journal of Biotechnology. Vol 7 (23), pp. 42984300

Clare, J. (2002). Daphnia an Aquarist's Guide. Dikutip dari http//www.caudata.org/daphnia

Connell, D.W dan Miller, G.J. (1995). Kimia dan Ekotoksikologi Pencemaran. Jakarta. UI Press.

Darmono. (1995). Logam dalam Sistem Biologi Mahkluk Hidup. Jakarta. UI press.

Duffus, J. H. (1980). Environmental Toxicology. London. Edward Arnorld Pub.Ltd.

Effendi, H. (2003). Telaah Kualitas Air Bagi Pengelolaan Sumber Daya dan Lingkungan Perairan. Yogyakarta. Kanisius.

Ernawati, (2010). Kerang bulu (Anadara inflata) Sebagai Bioindikator Pencemaran Logam Berat Timbal $(\mathrm{Pb})$ dan Cadmium $(\mathrm{Cd})$ di Muara Sungai Asahan. Tesis. Program Studi Magister Biologi, FMIPA, Universitas Sumatera Utara.

Ghazy, M. M. dan Habashy, M. M. (2003). Experimemtal Toxicity of Chromium to Two Freshwater Crustaceans; Daphnia magna and Macrobrachium resonbergii. Egypt Journal Aquatic. Biol. And Fish. Vol. 7. No. 3, pp. 49-70

Guilhermino, L. Diamantino, T., Silva, M. C., Soares, A. M. V. M. (1999). Acute Toxicity Test with Daphnia magna: An Alternative to Mammals in the Prescreening of Chemical Toxicity. Ecotoxicology and Environmental Safety. Vol. 46. pp. 357-362.

Palar, H. (2012). Pencemaran dan toksikologi logam berat. Jakarta. Rineka Cipta.

Pangkey, H. (2009). Daphnia dan Penggunaannya. Jurnal Perikanan dan Ilmu Kelautan, Vol V (3):33-36

Radini, D. N, dkk. (2004). Optimasi Suhu, $\mathrm{pH}$, serta Jenis Pakan pada Kultur Daphnia sp.. Jurnal Ilmiah Biologi. Ekologi dan Biodiversitas Tropika. Vol. (II), pp:23-28

Teodorovic. I, Pianojevic, I., Knezevic, P., Radak, S., dan Nemet, I. (2008). 
Sensitivity of Bacterial vs. Acute Daphnia magna toxicity tests to metals. Central European Journal of Biology.

Vol. 4 No. 4. pp. 482-492 